\title{
Histamine and Tyramine Content of South African Wine ${ }^{1}$
}

\author{
J. D. CILLIERS ${ }^{\mathrm{a}}$, C. J. VAN WYK ${ }^{\mathrm{b}}$
}

(a) Stellenbosch Farmers'Winery, P.O. Box 46, Stellenbosch 7600, Republic of South Africa.

(b) Department of Oenology, University of Stellenbosch, Stellenbosch 7600, Republic of South Africa.

Submitted for publication: June 1985

Accepted for publication: August 1985

Keywords: Amines, wine, malo-lactic bacteria

\begin{abstract}
The histamine content of 184 wines and tyramine content of 156 wines, produced in South Africa was measured. The histamine and tyramine content of the wine was bound to be similar to those of wines produced in other countries. The average histamine content of South African red wines that had undergone malo-lactic fermentation was more than double that of red wines that had not undergone malo-lactic fermentation. All the red wines containing relatively large amounts of histamine had pH's above 3,7. Six selected strains of malo-lactic bacteria were tested for their ability to form histamine and tyramine in white and red wine. No histamine or tyramine was formed.
\end{abstract}

Biogenic amines are usually bacterial degradation products of the corresponding amino acid and may be formed in almost all foods in varying amounts. A comprehensive review of their occurrence in a wide range of foods has recently been published by Smith (1981).

The biogenic amine content of alcoholic beverages has been much publicised as there has been evidence that these compounds could be responsible for some of the physiological changes that have been reported after the consumption of certain alcoholic beverages (Ienistea, 1971; Zee, et al., 1983). Lowenberg, et al., (1981) however, concluded that ingested alcohol stimulates the liberation of endogenous histamine and that histamine in wine has no effect on the human plasma histamine level.

The histamine content and to a lesser extent tyramine and other biogenic amines of European and American wines, has been determined (Subden, et al 1979; Zee et al., 1983). There have been no studies, however, on the histamine and tyramine content of South African wines.

Although bacteria responsible for malo-lactic fermentation have been indicated to form amines (Aerny, 1982), there is still a lack of information concerning the specific micro-organisms responsible for, and conditions favouring the formation of the amines during vinification.

\section{METHODS AND MATERIALS}

Analytical methods: The extraction and column chromatography procedure used by Yamamoto, Wakabayashi \& Makita (1980) for the gas-liquid chromatographic determination of tyramine in fermented food products was applied in the extraction, purification and concentration of histamine and tyramine in must and wine samples.

The following modifications to the method were used: Instead of adding a constant volume of $6 \mathrm{~N} \mathrm{HC1}$ to the $50 \mathrm{ml}$ portion of the must or wine sample, the $\mathrm{pH}$ of the sample was adjusted to 0,8 with the $\mathrm{HCl}$. A two percent perchloric acid solution was found to be sufficient to transfer the oily residue into a $25 \mathrm{ml}$ volumetric flask.

The method suggested by Lindroth \& Mopper (1979) for the HPLC determination of subpicomole amounts of amino acids by percolumn fluorescence derivitisation with o-phthaldialdehyde (OPT) was used as a basis for the development of the method for the separation and quantification of histamine and tyramine in the prepared samples.

One hundred microlitres of OPT reagent was added to $100 \mu \mathrm{l}$ of the prepared sample in a $5 \mathrm{ml}$ glass tube. The mixture was allowed to react for exactly one minute before injection onto the HPLC column.

Histamine dihydrochloride, tyramine hydrochloride and OPT were obtained from Sigma Chemical Co. Standard solutions of histamine and tyramine (as free base) were prepared in water, and aliquots were taken for the preparation of the calibration curve and for the calculation of the recovery rate from the wine samples. All other chemicals were reagent grade unless otherwise stated.

Analysis was performed on a Varian Model 5000 liquid chromatograph, equipped with a Varian Fluorichrom fluorescence detector and a Varian Vista 401 chromatography data system. The HPLC parameters used for the separation and detection of histamine and tyramine are summarised in Table 1.

TABLE 1

HPLC parameters used for the separation and detection of histamine and tyramine

\begin{tabular}{l|l}
\hline Parameter & \\
\hline Column: & Micro Pack MCH-5 \\
& $(4 \mathrm{~mm}$ ID $\times 30 \mathrm{~cm})$ \\
Column temperature: & $30^{\circ} \mathrm{C}$ \\
Mobile phase: Methanol: $\quad$ Phosphate buffer (pH 6,78): & $35 \%$ \\
& $0,7 \mathrm{ml} . \mathrm{min}^{-1}$ \\
Flow rate: & $360 \mathrm{~nm}$ \\
Detector: Excitation wavelength: & $460 \mathrm{~nm}$ \\
\multicolumn{2}{|l}{ Emmission wavelength: }
\end{tabular}

Figure 1 illustrates the degree of separation of histamine and tyramine from interfering compounds and the retention times of the amines. The procedure used for extracting histamine and tyramine was such that their concentrations

'Extract from the M.Sc. (Agric.)-thesis by the first author, University of Stellenbosch, 1983.

Special gratitude is extended to Stellenbosch Farmers' Winery for the various ways in which they made this investigation possible. 
TABLE 2

Mean, average percentage recovery, standard deviation and coefficient of variation for histamine and tyramine

\begin{tabular}{c|c|c|c|c}
\hline Amine & Mean' & $\begin{array}{c}\text { Mean Average } \\
\text { Percentage Recovery }\end{array}$ & $\begin{array}{c}\text { Standard } \\
\text { Deviation }\end{array}$ & $\begin{array}{c}\text { Coefficient of } \\
\text { Variation }\end{array}$ \\
\hline Histamine & 2,52 & 99,21 & 0,12 & 4,64 \\
Tyramine & 2,48 & 83,78 & 0,08 & 3,26 \\
\hline
\end{tabular}

$1=5$ replicates

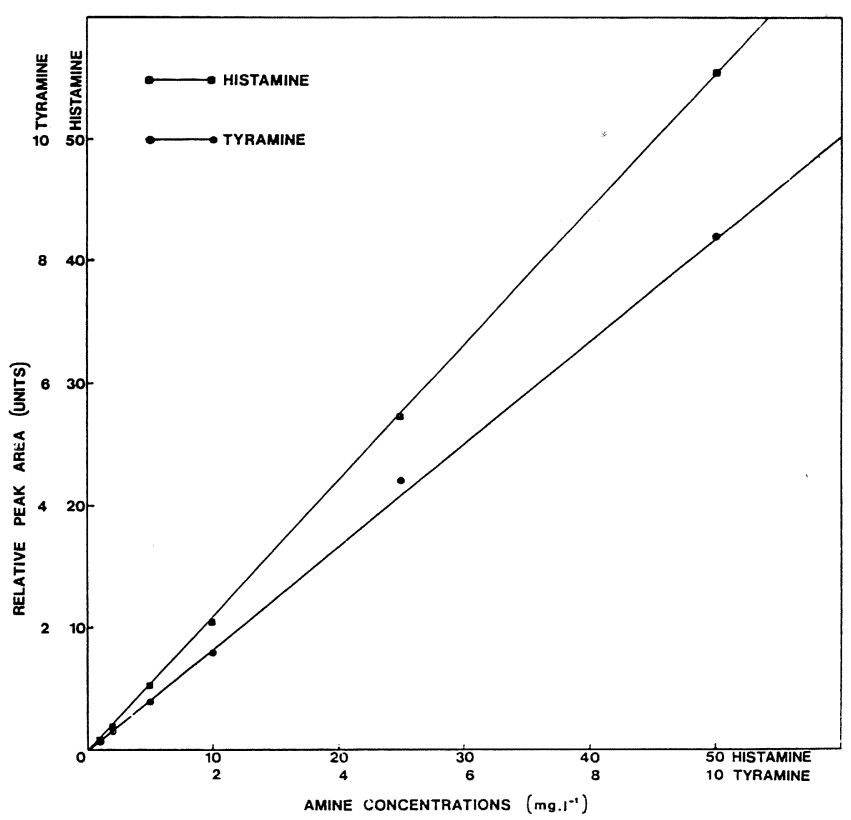

FIG. 2

Standard graph of relative peak areas of amines in relation to concentration of amines.

respectively. The standard deviation for histamine was 0,12 and for tyramine 0,08 (Table 2 ). The detector response was linear over the range 0 to $50 \mathrm{mg} \cdot \ell^{-1}$ for histamine and 0 to $10 \mathrm{mg} \cdot \ell^{-1}$ for tyramine (Figure 2 ).

The total soluble solids content of the must was measured with the aid of a hydrometer, calibrated in degrees Balling (Brix). Towards the end of fermentation the sugar content of the must was monitored by using a Clinitest kit (Ames Company) according to the procedure prescribed by the manufacturer.

The $\mathrm{pH}$ of must and wine samples was measured with a Beckman Model 3500 digital pH meter and a combination $\mathrm{pH}$ electrode.

Total acidity of samples was measured by titrating

FIG. 1 $25 \mathrm{ml}$ of must or wine with $0,33 \mathrm{~N} \mathrm{NaOH}$ to an end point of $\mathrm{pH} 7$.

The paper chromatographic procedure of Kunkee (1968) was used to determine the presence or absence of malic and lactic acid in wine samples. If malic acid was absent, it was assumed that the wine had undergone malolactic fermentation.

The free and total $\mathrm{SO}_{2}$ content of samples was deterliquid chromatographic procedure (Figure 1).

The mean average percentage recovery of histamine $\left(2,54 \mathrm{mg} \cdot \ell^{-1}\right)$ and tyramine $\left(2,96 \mathrm{mg} \cdot \ell^{-1}\right)$ was 99,2 and 83,8 mined according to the Ripper method (Amerine \& Ough, 1980). 
Materials: Various wines produced and commercially available in South Africa were analysed.

Wines were also made from Chenin blanc and Pinotage grapes from the Stellenbosch district in the following three ways. Chenin blanc grapes were crushed and destalked in the normal way. While the pomace was thoroughly mixed, it was divided into two lots. The one lot was treated as for normal white wine production. Must was separated from skins in a static separator and left to settle overnight at $14^{\circ} \mathrm{C}$. $\mathrm{No} \mathrm{SO}_{2}$ was added. The other lot was treated as for red wine production according to the thermovinification method. The Pinotage grapes were also treated after crushing and destalking, and subsequently pressed, according to the thermovinification method. Each quantity of must was then divided into 14 lots of 3,5 litres. To each lot $20 \mathrm{mg} \cdot \ell^{-1}$ of $\ell$-histidine (4 percent stock solution) and $20 \mathrm{mg} \cdot \ell^{-1}$ of $\ell$-tyrosine (4 percent stock solution) was added.

All lots were then inoculated with 5 percent Saccharomyces cerevisiae (WE 500) yeast, prepared from dried yeast the previous day. Bacteria started cultures were then added $(0,5$ percent $)$ to the individual musts as summarised in Table 3. All treatments were duplicated.

\section{TABLE 3}

Bacteria starter cultures added to individual musts

\begin{tabular}{l|l}
\hline Treatment No & Bacteria used \\
\hline 1. (a), (b), (c) & No bacteria added (control) \\
2. (a), (b), (c) & Leuconostoc oenos (PSU-1) \\
3. (a), (b), (c) & Leuconostoc oenos (France) \\
4. (a), (b), (c) & Lactobacillus (Equilait) \\
5. (a), (b), (c) & Pediococcus cerevisiae \\
6. (a), (b), (c) & Lactobacillus plantarum \\
7. (a),(b),(c) & Lactobacillus buchnerii \\
\hline
\end{tabular}

(a) White wine (Normal wine making procedure)

(b) White wine (thermovinification)

(c) Red wine (thermovinification)

The must and subsequent wine was kept in a waterbath at $20^{\circ} \mathrm{C}$ until alcoholic as well as malo-lactic fermentation was completed. The wines were then racked, $60 \mathrm{mg} . \ell^{-1} \mathrm{SO}_{2}$ added and stored at $0^{\circ} \mathrm{C}$ until analysed.

\section{RESULTS}

Histamine and tyramine content of South African wines: The histamine content of 184 commercial wines averaged $3,1 \mathrm{mg} \cdot \mathrm{l}^{-1}$. The wines analysed include $117 \mathrm{red}$ wines, 62 white wines and five rosé wines. The average histamine content of the red wines was $4,8 \mathrm{mg} \cdot \mathrm{l}^{-1}$. A summary of the different amounts of histamine detected in the wines is shown in Figure 3. Most of the wines ( 88,9 percent) had a histamine content of less than $10 \mathrm{mg} \cdot \ell^{-1}$. The average histamine content of the 91 red wines in which no malic acid could be detected and had presumably undergone malo-lactic fermentation, was $5,4 \mathrm{mg} \cdot l^{-1}$, compared to an average of $2,5 \mathrm{mg} \cdot l^{-1}$ for the 26 red wines in which malic acid was present and which presumably had not undergone malo-lactic fermentation. The highest histamine content measured in a red wine was $49,1 \mathrm{mg} . l^{-1}$. This wine was made from Pinotage grapes, had undergone malolactic fermentation and was of 1974 vintage.

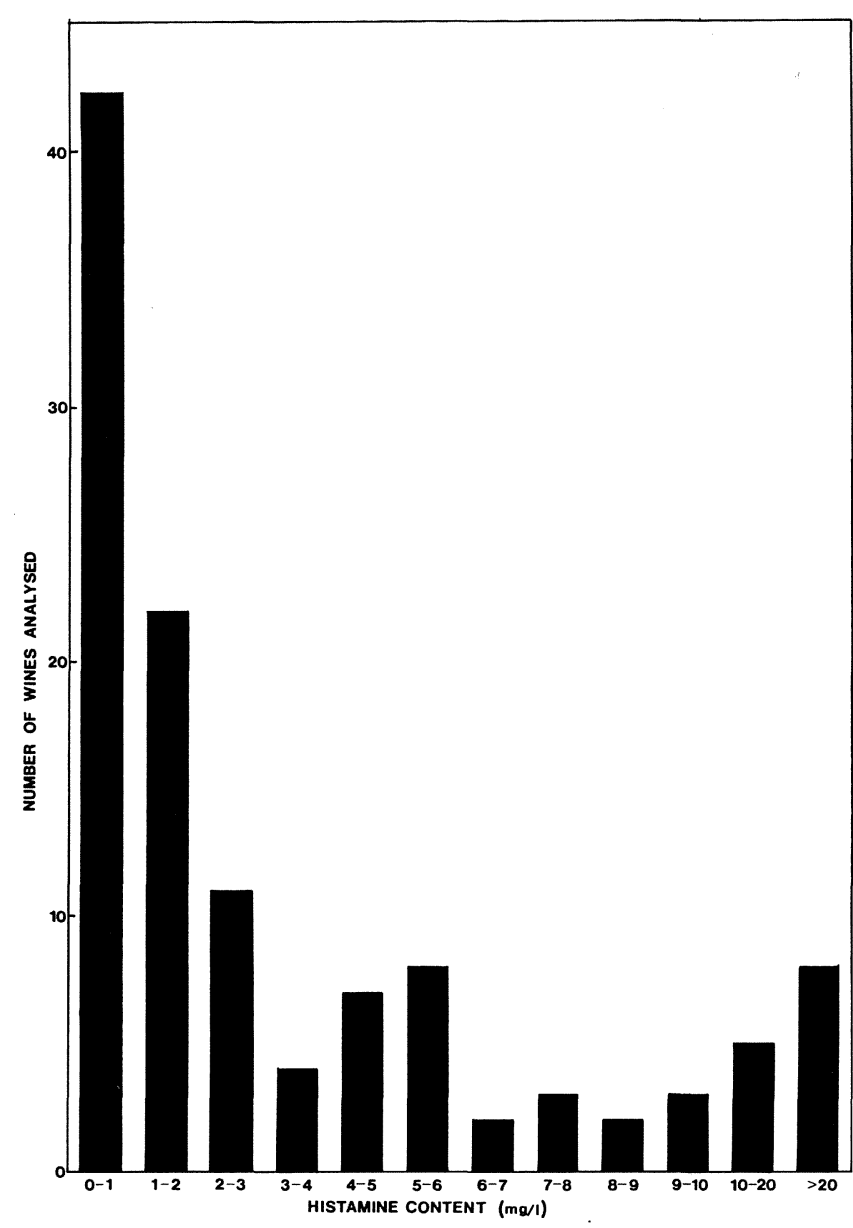

FIG. 3

Histamine content of South African commercial red wines.

The average histamine content of the red wines with high pH's was higher than the average histamine content of red wines with low pH's (Table 4). The average $\mathrm{pH}$ of the red wines analysed was 3,77 . All the wines containing more than $10 \mathrm{mg} . \mathrm{l}^{-1}$ of histamine had pH's above 3,7. Of the 25 red wines which contained malic acid and were accordingly classified as wines which had not undergone malo-lactic fermentation, six wines had a histamine content of more than $5 \mathrm{mg} \cdot \ell^{-1}$ the highest being $13,4 \mathrm{mg} \cdot \ell^{-1}$.

TABLE 4

Histamine content of South African commercial red wines per wine $\mathrm{pH}$ level

\begin{tabular}{l|r|r|r|r|r|r}
\hline \multirow{2}{*}{$\mathrm{pH}$} & \multicolumn{5}{|c|}{ Histamine mg. $\ell^{-1}$} & \multirow{2}{*}{ Number of wines } \\
\cline { 2 - 6 } & $<1$ & $1-5$ & $5-10$ & $>10$ & Average & \\
\hline$<3,4$ & 4 & & & & 0,1 & 4 \\
$3,4-3,5$ & 3 & 3 & & & 1,0 & 6 \\
$>3,5-3,6$ & 5 & 8 & & & 1,1 & 13 \\
$>3,6-3,7$ & 6 & 7 & 4 & & 2,7 & 17 \\
$>3,7-3,8$ & 6 & 6 & 7 & 1 & 4,7 & 20 \\
$>3,8-3,9$ & 9 & 14 & 4 & 5 & 5,5 & 32 \\
$>3,9-4,0$ & 5 & 4 & 3 & 3 & 4,8 & 15 \\
$>4,0$ & 4 & 2 & & 4 & 14,8 & 10 \\
\hline Total & 42 & 44 & 18 & 13 & 4,8 & 117 \\
\hline
\end{tabular}


The average histamine content of the white wines was $0,1 \mathrm{mg} . \mathrm{l}^{-1}$. None of the wines had undergone malo-lactic fermentation, and all contained less than $1 \mathrm{mg} \cdot \mathrm{l}^{-1}$ of histamine. The average $\mathrm{pH}$ of the white wines was 3,45 .

The average histamine content of the rosé wines was $1.03 \mathrm{mg} \cdot \mathrm{l}^{-1}$. None of the rosé wines had undergone malolactic fermentation.

The tyramine content of 156 commercial wines averaged $0,4 \mathrm{mg} \cdot \ell^{-1}$. The wines include 105 red wines, 47 white wines and four rosé wines.

The average tyramine content of the 105 red wines was $0,5 \mathrm{mg} . l^{-1}$. The 82 red wines which had undergone malolactic fermentation had an average tyramine content of $0,6 \mathrm{mg} \cdot \ell^{-1}$ compared to the $0,2 \mathrm{mg} \cdot \ell^{-1}$ of the 23 wines which had not undergone malo-lactic fermentation. Most of the

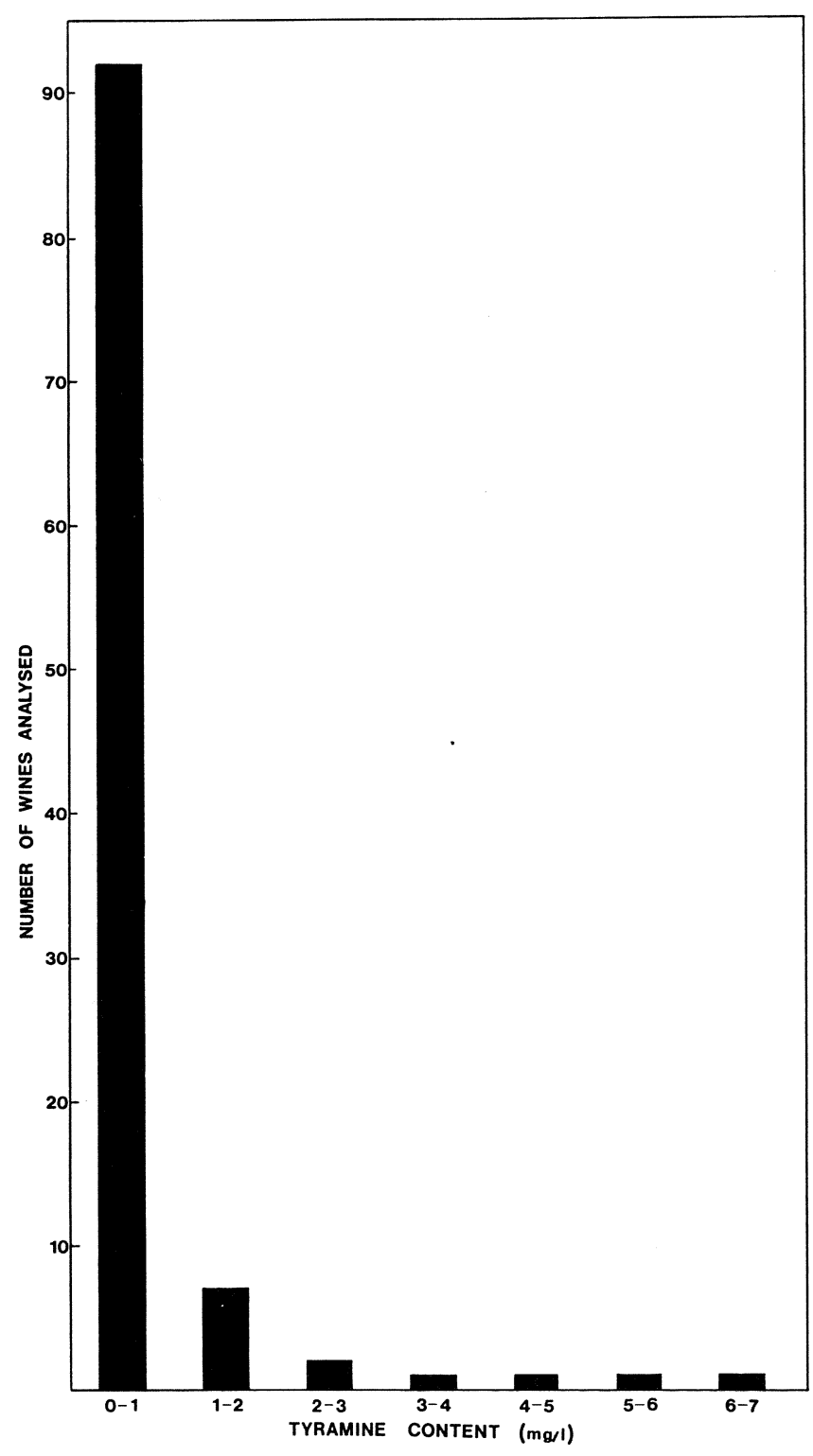

FIG. 4

Tyramine content of South African commercial red wines. wines ( 87,6 percent) had a tyramine content of less than $1 \mathrm{mg} . \mathrm{l}^{-1}$ (Figure 4). There seems to be no relationship between the $\mathrm{pH}$ of the red wines and their tyramine content (Table 5). The highest tyramine content measured in a red wine was $6,4 \mathrm{mg} . \mathrm{l}^{-1}$. The wine was made from Shiraz grapes, had undergone malo-lactic fermentation and was of 1980 vintage.

TABLE 5

Tyramine content of South African commercial red wines per wine $\mathrm{pH}$ level

\begin{tabular}{l|r|c|c|c|c|c}
\hline \multirow{2}{*}{\multicolumn{1}{c|}{$\mathrm{pH}$}} & \multicolumn{5}{|c|}{ Tyramine mg. $\ell^{-1}$} & \multirow{2}{*}{ Number of wines } \\
\cline { 2 - 6 } & $<1$ & $1-3$ & $3-5$ & $>5$ & Average & \\
\hline$<3,4$ & 3 & & & & 0,05 & 3 \\
$3,4-3,5$ & 5 & 1 & & & 0,63 & 6 \\
$>3,5-3,6$ & 12 & & & & 0,25 & 12 \\
$>3,6-3,7$ & 11 & 2 & 2 & 1 & 1,31 & 16 \\
$>3,7-3,8$ & 15 & 4 & & & 0,42 & 19 \\
$>3,8-3,9$ & 29 & & & 1 & 0,31 & 30 \\
$>3,9-4,0$ & 11 & & & & 0,15 & 11 \\
$>4,0$ & 6 & 2 & & & 0,65 & 8 \\
\hline Total & 92 & 9 & 2 & 2 & 0,50 & 105 \\
\hline
\end{tabular}

The average tyramine content of the 47 white wines was less than $0,1 \mathrm{mg} \cdot \mathrm{l}^{-1}$, the highest value obtained being $2,1 \mathrm{mg} \cdot l^{-1}$. All the white wines analysed had not undergone malo-lactic fermentaion.

The average tyramine content of the four rosé wines was $0,1 \mathrm{mg} \cdot \ell^{-1}$, all the wines contained less than $0,3 \mathrm{mg} \cdot \ell^{-1}$ of tyramine.

Influence of malo-lactic fermentaion on the formation of amines: The histamine and tyramine content of wines made by normal and thermovinification procedures and had undergone malo-lactic fermentation by various bacterial strains is reported in Table 6 . All the wines contained less than $0,5 \mathrm{mg} \cdot \mathrm{l}^{-1}$ of histamine. No tyramine was detected in any of them.

TABLE 6

The influence of wine type, method of production and bacterial strain on the formation of histamine and tyramine

\begin{tabular}{|c|c|c|c|c|c|c|}
\hline \multirow[t]{2}{*}{ Type of Bacteria } & \multicolumn{2}{|c|}{$\begin{array}{c}\text { White wine } \\
\text { (Normal wine } \\
\text { making procedure) }\end{array}$} & \multicolumn{2}{|c|}{$\begin{array}{c}\text { White wine } \\
\text { (Thermovinification) }\end{array}$} & \multicolumn{2}{|c|}{$\begin{array}{c}\text { Red Wine } \\
\text { (Thermovinification) } \\
\end{array}$} \\
\hline & Histamine & Tyramine & Histamine ${ }^{1}$ & Tyramine & Histamine' & Tyramine \\
\hline Control $^{3}$ & 0,2 & 0 & 0,2 & 0 & 0,3 & 0 \\
\hline PSU-1 & 0,5 & 0 & 0,1 & 0 & 0,2 & 0 \\
\hline L. oenos & 0,2 & 0 & 0,1 & 0 & 0,2 & 0 \\
\hline Equilait & -2 & 0 & 0,2 & 0 & 0,2 & 0 \\
\hline P. cerevisiae & 0,3 & 0 & 0,2 & 0 & 0,2 & 0 \\
\hline L. plantarum & 0,4 & 0 & 0,2 & 0 & 0,2 & 0 \\
\hline L. buchnerii & 0,3 & 0 & 0,1 & 0 & 0,3 & 0 \\
\hline
\end{tabular}

'mg. $\ell^{-1}$

${ }^{2}$ Did not undergo malo-lactic fermentation.

${ }^{3}$ Was not inoculated with bacteria, only yeast.

The analyses of the different musts used to determine the effect of bacterial strain on the amount of amines formed, are summarised in Table 7. Only the Pinotage must contained traces of histamine. None of the musts contained tyramine. 
TABLE 7

Analyses of musts used to determine the effect of malo-lactic bacteria on the formation of amines

\begin{tabular}{l|c|c|c}
\hline \multicolumn{1}{c|}{ Analysis } & Chenin blanc & $\begin{array}{c}\text { Chenin blanc } \\
\text { (Thermovini- } \\
\text { fication) }\end{array}$ & $\begin{array}{c}\text { Pinotage } \\
\text { (Thermovini- } \\
\text { fication) }\end{array}$ \\
\hline Free $\mathrm{SO}_{2}$ mg. $\ell^{-1}$ & 3 & 7 & 15 \\
Total SO $\mathrm{Sg}_{2} \ell^{-1}$ & 15 & 17 & 30 \\
pH & 3,46 & 3,59 & 3,58 \\
Total acidity g. $\ell^{-1}$ & 5,2 & 6,0 & 6,3 \\
Sugar content $\left({ }^{\circ} \mathrm{B}\right)$ & 20,4 & 21,0 & 25,6 \\
Free amino nitrogen & 1071 & 1280 & 1300 \\
Histamine mg. $\ell^{-1}$ & 0 & 0 & 0,1 \\
Tyramine mg. $\ell^{-1}$ & 0 & 0 & 0 \\
\hline
\end{tabular}

\section{DISCUSSION AND CONCLUSIONS}

Histamine and tyramine content: The average histamine content of wines produced in South Africa is very similar to those produced in other countries. (Ough, 1971; Mayer \& Pause, 1973; Subden et al., 1979; Zee et al., 1983). The average histamine content of South African red wines that had undergone malo-lactic fermentation was more than double that of red wines that had not undergone malo-lactic fermentation. It therefore appears that bacteria responsible for malo-lactic fermentation are responsible for high histamine levels. However, some wines that presumably had not undergone malo-lactic fermentation had histamine contents of more than $5 \mathrm{mg} \cdot l^{-1}$, indicating that it is not only the malo-lactic bacteria that could be responsible for high histamine levels.

Conditions during malo-lactic fermentation, as well as during wood maturation of red wines could be favourable for the growth of other bacteria which could produce histamine. In most cases the addition of $\mathrm{SO}_{2}$ after alcoholic fermentation is limited so as not to inhibit the bacteria responsible for malo-lactic fermentation, thus also making conditions favourable for other bacteria. Many red wines undergo malo-lactic fermentation spontaneously during wood maturation indicating that malolactic, as well as other bacteria, survive in the cooperage.

All the South African red wines containing more than $10 \mathrm{mg} \cdot \ell^{-1}$ of histamine had $\mathrm{pH}$ 's above 3,77. The tendency of the South African red wines with higher $\mathrm{pH}$ 's to have a higher histamine content is in good agreement with results reported by Mayer (1976) and Aerny (1982). It would seem that many South African red wines have the potential to have high histamine contents as the average $\mathrm{pH}$ of the red wines analysed was 3,77. Therefore wines, especially those which have to undergo malo-lactic fermentation, should have pH's of less than 3,77 to ensure low histamine levels.

The red wines analysed contained much more histamine than the white wines.

\section{Probable reasons for this phenomenom are:}

Red wine vinification is usually carried out in the presence of grape pulp, and this causes a higher amount of histidine in the must (Zee et al., 1983).
Many red wines undergo malo-lactic fermentation spontaneously, specially during wood maturation. Histamine could be produced by bacteria responsible for the malo-lactic fermentation or by contaminating bacteria developing under conditions favourable for their growth.

The practice of settling must before alcoholic fermentation, racking off the lees, adding $\mathrm{SO}_{2}$ as soon as fermentation is completed and the filtration of the wine at an early stage during the vinification of white wines, lower the histidine as well as total nitrogen content and minimize the possibility of bacterial contamination (Amerine \& Kunkee, 1968; Amerine \& Joslyn, 1973).

Bentonite partially absorbs histamine (Jacob, 1968). Bentonite is used more often during white wine vinification than during red wine vinification and therefore also contributes to the lower histamine levels of the white wines.

The tendency of white wines to have lower $\mathrm{pH}$ values than red wines (average $\mathrm{pH} 3,45$ for white wines, compared to $\mathrm{pH} 3,77$ for red wines) also contributes to lower histamine levels of the white wines.

The rosé wines analysed, contained more histamine than the white wines, but less than the red wines. As rosé wines are often produced by blending white and red wines, average histamine content of such wines can be expected to be more than that of white wines, but less than that of red wines.

The average tyramine content of the South African wines is much lower than the values reported by Mayer \& Pause (1973) and Zee et al., (1983). Sen (1969) and Zappavigna \& Cerutti (1973), however, reported tyramine contents in wines which are comparable with those of South African wines. One of the probable reasons for the relatively big differences in the average tyramine content of wines as reported, could be as a result of the varied methods used for their determination.

As was the case for histamine, differences were observed in the average tyramine content of red wines that had undergone malo-lactic fermentation compared to wines that had not undergone malo-lactic fermentation. Although the average tyramine values were much lower, and the differences smaller, the same tendencies are apparent. Wines which had undergone malo-lactic fermentation had an average tyramine content of $0,6 \mathrm{mg} . l^{-1}$ compared to the $0,2 \mathrm{mg} \cdot l^{-1}$ of the wines which had not undergone malo-lactic fermentation.

The tyramine content of the South African red wines does not seem to be dependant on the $\mathrm{pH}$ of the wines. Wines with high $\mathrm{pH}$ 's do not seem to have higher tyramine levels as found with histamine.

Although the tyramine content of the wines analysed was much lower than the histamine content, similar differences between red and white wines were observed, with the average tyramine content of red wines being $0,5 \mathrm{mg} . l^{-1}$ compared to $0,1 \mathrm{mg} . l^{-1}$ for white wines. The same reasoning for the differences in the histamine content of red and white wines would apply to the differences in the tyramine content.

Factors influencing the formation of amines during malolactic fermentation: Three types of wine were made to investigate the ability of bacteria, used for malo-lactic fermentation, to form histamine and tyramine. White wine was made according to the traditional method, as 
well as according to the red wine method of thermovinification and a red wine was made by the thermovinification method. The six bacterial strains used did not produce histamine or tyramine. It therefore seems that the ability to produce histamine and tyramine occurs infrequently amongst the bacteria that could be used for malolactic fermentation. Previous investigators have also indicated that only certain specific strains of malo-lactic bacteria possess the ability to decarboxylate histidine and tyrosine (Lagerborg \& Clapper, 1952; Rodwell, 1953). Of various malo-lactic bacteria isolated from wine by LafonLafourcade (1975), only one strain of Leuconostoc had the ability to produce histamine. Weiller \& Radler (1976) tested more than a hundred strains of lactic acid bacteria isolated from wine and found only a single strain of Pediococcus able to decarboxylate histidine. None of the bacteria used in this study, including a Pediococcus strain as well as two Leuconostoc strains produced histamine or tyramine.

The high average histamine content of the commercial red wines that had undergone malo-lactic fermentation, could also have been partly due to bacteria other than those responsible for malo-lactic fermentation. Although most studies concerning bacteria in must and wine are limited to lactic acid bacteria (Du Plessis \& Van Zyl, 1963; Costello, Morrison, Lee \& Fleet, 1983) the presence of other bacteria such as Pseudomonas, Micrococcus an Bacillus in must has been indicated (Amerine \& Kunkee, 1968).

\section{LITERATURE CITED}

AERNY, J., 1982. L'histamine, présence dans les denrées alimentaires et dans le vin en particulier. Revue suisse Viti. Arboric. Hortic. 14, 7-13.

AMERINE, M. A., \& JOSLYN, M. A., 1973. Table wines, the technology of their production. 2nd ed. Univ. California Press, Berkeley.

AMERINE, M. A., \& KUNKEE, R. E., 1968. Microbiology of winemaking. Ann. Rev. Microbiol. 22, 323-358.

AMERINE, M. A., \& OUGH, C. S., 1980. Methods for analysis of musts and wines. John Wiley \& Sons, Inc., New York.

COSTELLO, P. J., MORRISON, G. J., LEE, J. H. \& FLEET, G. H., 1983. Numbers and species of lactic acid bacteria in wines during vinification. Food Technol. Aust. 35, 14-18.
DU PLESSIS, L. DE W., \& VAN ZYL, J. A., 1963. The microbiology of South African winemaking. Part IV. The taxonomy and incidence of lactic acid bacteria from dry wines. S. Afr. J. Sci. 6, 261-273.

IENISTEA, C., 1971. Bacterial production and destruction of histamine in foods, and food poisoning caused by histamine. Die Nahrung 15 , 109-113.

JACOB, VON L., 1968. Die adsorption von histamin und acetylocholin bei der bentonitbehandlung von wein. Weinberg und Keller 15, 555-560.

KUNKEE, R. E., 1968. Simplified chromatographic procedure for detection of malo-lactic fermentation. Wines \& Vines 49, 23-24.

LAFON-LAFOURCADE, S., 1975. L'histamine des vins. Conn. vigne et vin 2, 103-115.

LAGERBORG, V. A., \& CLAPPER, W. E., 1952. Amino acid decarboxylase of lactic acid bacteria. J. Bact. 63, 393-397.

LINDROTH, P., \& MOPPER, K., 1979. High performance liquid chromatographic determination of subpicomole amounts of amino acids by precolumn fluorescence derivatization with o-phthaldialdehyde. Anal. Chem. 51, 1667-1674.

LOWENBERG, D. W., OUGH, C. S., LEPKORSKY, S., \& FURUTA, F. F., 1981. The effect of ethanol and wine on the plasma histamine level of chickens and man. Am. J. Enol. Vitic. 32, 128-131.

MAYER, K., 1976. Biogenic amines in food. Investigation in wine and sauerkraut. Qual. Plant.-pl. Fds. Hum. Nutr. 16. 263-269.

MAYER, K., \& PAUSE, G., 1973. Nicht-fluchtige biogene amine in wein. Mitt. Lebensm. Unters. Hyg. 64, 171-179.

OUGH, C. S., 1971. Measurement of histamine in California wines. $J$ Agr. Food Chem. 19, 241-244.

RODWELL, A. W., 1953. The occurrence and distribution of aminoacid decarboxylases within the genus Lactobacillus. J. gen. Microbiol. 8, 224-232.

SEN, M. P., 1969. Analysis and significance of tyramine in foods. $J$. Food Sci. 34, 22-26.

SMITH, T. A., 1981. Amines in food. Food Chemistry 6, 169-200.

SUBDEN, R. E., DUITSCHAEVER, C., KAISER, K., \& NOBLE, A. C., 1979. Histamine content of Canadian wines determined by reverse phase high performance liquid chromatography. Am. J. Enol. Vitic. 30, 10-21.

VOS, P. J. A., \& GRAY, R. S., 1979. The origin and control of hydrogen sulphide during fermentation of grape must. Am. J. Enol. Vitic. 30, 187-197.

WEILLER, H. G., \& RADLER, F., 1976. On the metabolism of amino acids by lactic acid bacteria isolated from wine. Z. Lebensm. Unters.Forsch. 161, 259-277.

YAMAMOTO, S., WAKABAYASHI, S., \& MAKITA, M., 1980. Gasliquid chromatographic determination of tyramine in fermented food products. J. Agric. Food Chem. 28, 790-793.

ZAPPAVIGNA, R., \& CERUTTI, G., 1973. Non volatile amines in Italian wines. Lebensm.-Wiss. $u$. Technol. 6, 151-152.

ZEE, J. A., SIMARD, R. E., L'HEUREUX, L., \& TREMBLAY, J. 1983. Biogenic amines in wines. Am. J. Enol. Vitic. 34, 6-9. 